\title{
PERILAKU PEMILIH DI KECAMATAN JAGAKARSA JAKARTA SELATAN DALAM PEMILIHAN GUBERNUR/WAKIL GUBERNUR DKI JAKARTA TAHUN 2017
}

\author{
Odeles Kirawan Emka ${ }^{1}$ \\ ${ }^{1}$ Program Studi Pascasarjana Ilmu Politik, Universitas Nasional \\ email : odeles.kirawan@gmail.com
}

Korespondensi : odeles.kirawan@gmail.com

\begin{abstract}
The election of the Governor and Deputy Governor of DKI Jakarta in 2017, as is known, has raised the Anies-Sandi pair as the winner and is legitimate to lead DKI Jakarta until 2022. The Anies-Sandi pair is superior to the Ahok-Djarot pair who previously led DKI Jakarta. These political events have significantly led to very high political dynamics. However, it is necessary to look at voter behavior related to the 2017 DKI Jakarta Regional Election. In this paper we will look at voter behavior in the Jagakarsa District Area. This voter behavior will be seen from a sociological, psychological and rational choice approach.
\end{abstract}

Keywords: election , 2017 dki Jakarta, , voter behavior, democracy, election

\begin{abstract}
Abstrak
Pemilihan Gubernur dan Wakil Gubernur DKI Jakarta tahun 2017 lalu, sebagaimana diketahui telah memunculkan pasangan Anies-Sandi sebagai pemenangnya dan sah memimpin DKI Jakarta sampai dengan tahun 2022. Pasangan Anies-Sandi unggul atas pasangan Ahok-Djarot yang sebelumnya memimpin DKI Jakarta. Peristiwa politik tersebut secara nyata telah menimbulkan dinamika politik yang sangat tinggi. Namun demikian perlu kiranya untuk melihat perilaku pemilih terkait dengan Pilkada DKI Jakarta 2017 yang tersebut. Dalam penulisan ini akan di lihat perilaku pemilih di Wilayah Kecamatan Jagakarsa. Perilaku pemilih ini akan diihat dari pendekatan sosiologis, psikologis dan pilihan rasional.
\end{abstract}

Kata kunci : pilkada, dki jakarta 2017, perilaku pemilih, demokrasi, pemilihan,

\section{PENDAHULUAN}

Pilkada DKI Jakarta menampilkan dinamika yang sangat tinggi. Bukan hanya isu-isu di seputar Pilkada yang menyedot perhatian publik, saling susul perolehan dukungan juga mewarnai kontestasi menjelang pelaksanaan Pilkada. Pasangan AHY-Sylvie hadir paling akhir, tetapi mampu tampil memukau diawal kemunculan, sebelum akhirnya menurun dan tersingkir di putaran pertama. Sebaliknya, pasangan Anies-Sandi kurang meyakinkan di bulan-bulan pertama, tetapi naik pesat sampai menduduki posisi kedua di putaran pertama. Sedangkan 
incumbent, Ahok-Djarot, yang sebelumnya unggul harus mengalami penurunan selama berbulan-bulan, sebelum akhirnya rebound dan menduduki posisi tertinggi di putaran pertama.

Pilkada itu sendiri memang berlangsung pada dua putaran. Putaran pertama dilaksanakan pada 15 Februari 2017 dan putaran kedua dilaksanakan 19 April 2017. Pada putaran pertama diketahui hasilnya adalah pasangan nomor urut 1. AHY-Sylvi (Agus Harimurti Yudhoyono, M.Sc., M.P.A., M.A. dan Prof. Dr. Hj. Sylviana Murni, S.H.,M.Si) berhasil memperoleh suara sebanyak 936.461 suara (17.06\%); Pasangan dengan nomor urut 2. Ahok-Djarot (Ir. Basuki Tjahaja Purnama, M.M. dan Drs. H. Djarot Saiful Hidayat, M.S.) memperoleh suara sebesar 2.357.785 suara $(42.96 \%)$ dan pasangan dengan nomor urut 3. Anies-Sandi (Anies Baswedan, Ph.D. dan Sandiaga Salahuddin Uno) memperoleh suara sebesar 2.193.530 suara (39.97\%). Jumlah keseluruhan suara sah adalah 5.487.776 suara. Berikutnya pada putaran kedua, diketahui hasilnya adalah pasangan Anies-Sandi berhasil memenangkan Pilkada DKI Jakarta dengan jumlah perolehan suara sebanyak 3.240.987 suara (57,96 \%). Sedangkan pasangan Ahok-Djarot mengumpulkan suara sebesar 2.350.366 suara (42.04\%). Jumlah keseluruhan suara sah pada putaran kedua adalah 5.591.353 suara. (https://pilkada2017.kpu.go.id)

Secara umum, rincian perolehan suara itu, di Kepulauan Seribu, AhokDjarot memeroleh suara sebanyak 5.391 (38 persen), sedangkan Anies-Sandi unggul dengan perolehan suara 8.796 (62 persen) dengan total 14.187 suara sah. Di Jakarta Utara, Ahok-Djarot memeroleh suara sebanyak 418.068 (47 persen), sedangkan Anies-Sandi memperoleh 466.340 suara atau 52 persen suara dengan total 884.408 suara sah. Untuk perolehan suara di Jakarta Pusat, Ahok-Djarot memeroleh 243.416 suara atau 42 persen suara, sedangkan Anies-Sandi memeroleh 333.033 suara atau 57 persen suara dengan total 576.449 suara sah. Di Jakarta Barat, Ahok-Djarot memeroleh 611.759 suara atau 47 persen suara, sedangkan Anies-Sandi memeroleh 684.980 suara atau 52 persen suara dengan total 1.296.739 suara sah. Di Jakarta Timur, Ahok-Djarot memeroleh 612.093 suara atau 38 persen suara, adapun AniesSandi memeroleh 993.174 suara atau 61 persen suara dengan total 1.605.266 suara sah. Di Jakarta Selatan, Ahok-Djarot meperoleh 459.639 suara, sedangkan AniesSandi memeroleh 754.665 suara atau 62 persen suara dengan total 1.214 .304 suara sah.

Adapun rangking partisipasi pemilih tertinggi pertama berada di Kepulauan Seribu dengan persentase pemilih 87 persen, kedua di Jakarta Timur dengan persentase 78 persen, ketiga Jakarta Utara dengan persentase 77 persen, keempat Jakarta Barat dengan persentase 76 persen, kelima di Jakarta Pusat dengan persentase 76 persen, dan keenam di Jakarta Selatan dengan persentase 75 persen warga yang menggunakan hak memilih. Sehingga, tingkat partisipasi pemilih secara keseluruhan di tingkat Provinsi DKI Jakarta sebanyak 77, 08 persen. (Kompas.com 30/04/2017)

Kemenangan Anies-Sandi dalam Pilkada DKI Jakarta tersebut, mendapat pandangan yang beragam dari berbagai ahli. Siti Zuhro, seorang pengamat politik dari LIPI menyebutkan bahwa kemenangan Anies-Sandi tidak dapat dipisahkan dari faktor kehadiran Prabowo dalam masa kampanye Pilkada DKI Jakarta itu. Turun 
tangannya pimpinan tertinggi partai Gerindra, Prabowo Subianto dalam strategi pemenanangan calon gubernur dan wakil gubernur DKI Jakarta Anies Baswedan dan Sandiaga Uno, dipandang sebagai sebuah langkah penyempurnaan. Menurut Siti Zuhro pengamat politik sekaligus peneliti LIPI itu menyatakan bahwa Prabowo menggunakan secara maksimal dalam penggunaan mesin partai. Mesin partainya tidak hanya dihangatkan tapi digunakan secara maksimal. Menurut Zuhro lagi, Prabowo sudah bertindak sebagai pejuang yang menggunakan masa pendukungnya pada pilpres 2014 lalu untuk ikut memenangkan Anies-Sandi. Prabowo bertindak jadi lictery figther dan tentu dia punya mass political base dan punya dukungan masa yang cukup signifikan, bertolak dari pengalaman, pemilu 2014 lalu. (https://www.arah.com/article)

Selanjutnya adalah pandangan dari Dirga Ardiansyah, Manajer Riset Pusat Kajian Politik Fakultas Ilmu Sosial dan Politik UI. Menurutnya kemenangan AniesSandi adalah karena pasangan urut nomor dua, Ahok-Djarot tidak memiliki strategi komunikasi yang baik, sehingga kemenangan itu sulit dicapai. Strategi komunikasi tersebut harus meraih simpati banyak orang untuk meraih kursi gubernur. Menurut Dirga, pasangan Ahok-Djarot juga seharusnya menawarkan kebijakan yang memprioritaskan masyarakat kalangan bawah. Komunikasi tersebut didukung dengan kebijakan yang tidak menekan kaum bawah, seperti reklamasi dan penggusuran. Jadi bukan persoalan minoritas, melainkan kebijakannya yang tidak popular di masyarakat. Demikian menurut Dirga. (https://pilkada.tempo.co/read/news).

Berikutnya adalah menurut Eep Saefulloh Fatah sekaligus CEO Polmark Indonesia. Ia menyebut ada 5 (lima) faktor penyebab kemenangan Anies-Sandi dalam Pilkada DKI yang baru lalu tersebut. Pertama, Terkarantinanya pemilih Ahok. Maksudnya adalah jumlah pemilih Ahok-Djarot tidak meningkat dan tidak mengecil. Jumlah atau besaran pemilih Basuki-Djarot tidak meningkat dan tidak mengecil. Di putaran kedua bahkan mengalami penurunan. Kedua, kecilnya peningkatan partisipasi politik dikalangan pemilih Ahok-Djarot. Angka partisipasi dikalangan pemilih Ahok-Djarot hanya meningkat dari $77 \%$ menjadi $78 \%$. Ini mengulang seperti tahun 2012 yang hanya naik 2\%. Angka partisipasi memang mengalami kenaikan, tetapi kecil sekali, yaitu meningkat dari $77 \%$ menjadi $78 \%$. Dari putaran pertama ke putaran kedua mengalami peningkatan juga, bukan penurunan. Jadi hanya mengulang trend 2012. Meningkat 2\% saja. Ketiga, pengelolaan isu yang kurang baik oleh pasangan dan tim pemenangan Ahok-Djarot. Yang paling menentukan menurut Eep adalah pada saat-saat terakhir atau masa tenang. Yakni timbulnya isu sembako. Apa yang terjadi di akhir seperti masa tenang. Suasana kolektif yang mempengaruhi mereka, pada saat itu ada hujan sembako terjadi. Saya menduga secara kualitatif itu berfungsi negatif bagi yang berkampanye, itu pertama dalam sejarah pilkada membagikan sembako pada masa tenang dan memakai atribut kampanye. Keempat, adalah perlawanan terhadap keunikan TPS atau potensi kejahatan kecurangan pemilu. Menurutnya, indikasi ini datang pada putaran pertama yang terkonsentrasi pada tempat-tempat paslon tertentu. Adanya potensi kejahatan atau kecurangan pemilu di TPS-TPS tertentu menjadi faktor yang menghilangkan simpati warga masyarakat Jakarta. Di Jakarta 
ini ada 1.848 TPS yang terindikasi seperti itu. Indikasi itu datang dari pemilih tambahan, hampir 250 ribu daftar pemilih tambahan. Itu terkonsentrasi di tempattempat yang paslon tertentu berpotensi menang besar, Kelima, atau terakhir adalah faktor agama. Menurut Eep, itu memiliki pengaruh tertentu. Faktor agama dianggap sebagai air bah. Faktor agama tentu saja memiliki pengaruh tertentu dikarenakan AlMaidah. Saya ingin bilang kalau faktor agama itu seperti air bah. Penyebabnya adalah bendungan yang dibuka. Jadi, kalau ada pemimpin yang menjaga lisannya, masuk ke isu sensitif di negeri seperti Indonesia, maka harus terima konsekuensinya, demikian menurut Eep. (https://news.detik.com/berita)

Pengalaman Pilkada di Kecamatan Jagakarsa, Jakarta Selatan, menampilkan hal yang hampir mirip dengan tinjauan umum untuk wilayah DKI Jakarta seperti yang dikemukakan oleh beberapa ahli tadi. Ada sebanyak 179.307 jumlah pemilih di Kecamatan Jagakarsa. Pasangan Ahok-Djarot memperoleh suara sebesar 62.867 suara $(35,06 \%)$ sedangkan pasangan Anies-Sandi memperoleh suara sebesar 116.440 suara $(64,94 \%)$. Pilkada DKI Jakarta di Kecamatan Jagakarsa dimenangkan oleh pasangan Anies-Sandi. Tngkat partisipasi pemilih di Kecamatan Jagakarsa dalam Pilkada DKI Jakarta 19 April 2017 tersebut adalah sebesar 79,9\%. (https://pilkada2017.kpu.go.id/hasil)

Sementara itu, peta pemilihan di Kecamatan Jagakarsa dalam Pilkada DKI 19 April 2017 adalah sebagai berikut, di Kelurahan Tanjung barat terdapat 31.501 jumlah pemilih, sedangkan yang menggunakan hak pilih adalah sebanyak 25.328 orang dengan tingkat partisipasi yaitu 80,4 persen. Suara sah adalah 25.037 suara, suara tidak sah adalah 290 suara. Jadi total suara adalah 25.327 suara. Jumlah TPS adalah 59 TPS. Dari jumah pemilih ini diketahui hasilnya di Kelurahan Tanjung Barat adalah pasangat nomor urut 2 yaitu Ahok-Djarot sebesar 7.828 suara (31.3\%), sedangkan pasangan nomor urut 3, yaitu Anies-Sandi adalah sebanyak 17.209 suara (68.7\%). Gambaran ini menunjukkan betapa partisipasi atau antusiasme pemilih cukup tinggi di Kelurahan Tanjung Barat. Sebagai perbandingan perlu kiranya melihat perolehan hasil suara di kelurahan lain dalam Kecamatan yang sama, seperti di Kelurahan Srengseng Sawah : 22.931 (64.6\%) untuk kemenangan Anies-Sandi, Kelurahan Lenteng Agung: 22.500 (66.5\%) untuk kemenangan Anies-Sandi, Kelurahan Jagakarsa : 23.703 (62.4\%) untuk kemenangan Anies-Sandi, dan Kelurahan Cipedak : 15.041 (66.0\%) untuk kemenangan Anies-Sandi. (https://pilkada2017.kpu.go.id/hasil)

Kepiawaian Tim Sukses memanfaatkan instrumen komunikasi massa juga turut memenangkan pasangan Anies-Sandi dalam Pilkada DKI Jakarta 2017 yang lalu. Kepiawaian tim sukses ini yang sangat baik memanfaatkan isu penggusuran dan reklamasi serta isu penistaan agama. bertambah baik tatkala mesin partai yang mengusungnya juga turut serta bekerja maksimal. Hampir semua partai pengusung (Gerindra, PKS dan PAN) dari tingkat pusat hingga ranting bekerja maksimal mensukseskan pasangan Anies-Sandi. Lalu, bagaimanakah sesungguhnya perilaku pemilih masyarakat di Kecamatan Jagakarsa, Jakarta Selatan pada Pemilihan Gubernur/Wakil Gubernur DKI Jakarta tahun 2017 yang lalu.

\section{TINJAUAN KONSEP}


Pemilihan Kepala Daerah secara langsung yang sering disebut sebagai pilkada menjadi sebuah perjalanan sejarah baru dalam dinamika kehidupan berbangsa di Indonesia. Pemilihan Kepala Daerah merupakan suatu proses pemilihan langsung oleh rakyat, rakyat menyeleksi secara langsung putra-putra terbaik dari daerah mereka. Mampu memimpin dan membawa daerah mereka menjadi lebih baik dan lebih maju, sehingga kesejahteraan masyarakat setempat dapat terpenuhi. Pemilihan Kepala Daerah dilaksanakan bukan hanya memilih penguasa daerah tetapi lebih merupakan mencari pemimpin yang mampu melayani dan mengabdi untuk kepentingan sebuah rakyatnya. Pola pikir lama yang lebih menempatkan kepala daerah sebagai penguasa yang harus diubah secara radikal menjadi pemimpin yang sesungguhnya bertugas memberikan pelayanan kepada masyarakat. (Kristiadi, 2008). Pemilihan Kepala Daerah secara langsung, memberikan peluang kepada masyarakat untuk ikut berpartisipasi dalam politik, agar terciptanya demokrasi dalam menjalankan pemerintahan. Berangkat dari beberapa gagasan di atas, peneliti menyimpulkan bahwa Pemilihan Kepala Daerah merupakan salah satu bentuk kegiatan dari pemilhan umum,

Perilaku pemilih terkait dengan semua pihak yang menjadi tujuan utama para kontestan untuk mereka pengaruhi dan yakinkan agar mendukung dan kemudian memberikan suaranya kepada kontestan yang bersangkutan. (Ibid). Dinyatakan sebagai pemilih dalam Pilkada yaitu mereka yang telah terdaftar sebagai peserta pemilih oleh petugas pendata peserta pemilih. Pemilih dalam hal ini dapat berupa konsituen maupun masyarakat pada umumnya. Konstiuen adalah kelompok masyarakat yang merasa diwakili oleh suatu ideologi tertentu yang kemudian termanifestasikan dalam institusi politik seperti partai politik dan seorang pemimpin. Perilaku pemilih dapat ditujukan dalam memberikan suara dan menentukan siapa yang akan dipilih menjadi Kepala Daerah dan Wakil Kepala Daerah dalam Pilkada secara langsung.

Pemberian suara dalam Pilkada secara langsung diwujudkan dengan memberikan suara pada pasangan calon Kepala Daerah dan Wakil Kepala Daerah yang didukungnya atau ditujukan dengan perilaku masyarakat dalam memilih pasangan Calon Kepala Daerah dan Wakil Kepala Daerah. Adapun perilaku pemilih menurut Surbakti adalah Akivitas pemberian suara oleh individu yang bekaitan erat dengan kegiatan pengambilan keputusan untuk memilih atau tidak memilih (to vote or not to vote) di dalam suatu pemilihan umum (Pilkada secara langsung). Bila voters memutuskan untuk memilih (to vote) maka voters akan memilih atau mendukung kandidat tertentu. (Surbakti, 1997).

Perilaku memilih atau perilaku politik adalah tindakan atau kegiatan seseorang atau kelompok dalam kegiatan politik. Surbakti, mengemukakan bahwa perilaku politik adalah sebagai kegiatan yang berkenaan dengan proses pembuatan dan keputusan politik. Perilaku politik merupakan salah satu unsur atau aspek perilaku secara umum. Di samping perilaku politik, masih terdapat perilaku-perilaku lain seperti perilaku organisasi, perilaku budaya, perilaku konsumen ekonomi, perilaku keagamaan, dan lain sebagainya. Perilaku politik meliputi tanggapan internal seperti persepsi, sikap, orientasi dan keyakinan serta tindakan-tindakan nyata seperti pemberian suara, protes, lobi, dan sebagainya. (Surbakti, 1992). 
Persepsi politik berkaitan dengan gambaran suatu obyek tertentu, baik mengenai keterangan, informasi dari sesuatu hal, maupun gambaran tentang obyek atau situasi politik dengan cara tertentu. (Putra, 2003). Sedangkan sikap politik adalah merupakan hubungan atau pertalian di antara keyakinan yang telah melekat dan mendorong seseorang untuk menanggapi suatu obyek atau situasi politik dengan cara tertentu. Sikap dan perilaku masyarakat dipengaruhi oleh proses dan peristiwa historis masa lalu dan merupakan kesinambungan yang dinamis. Peristiwa atau kejadian politik secara umum maupun yang menimpa pada individu atau kelompok masyarakat, baik yang menyangkut sistem politik atau ketidakstabilan politik, janji politik dari calon pemimpin atau calon wakil masyarakat yang tidak pernah ditepati dapat mempengaruhi perilaku politik masyarakat.

Salah satu cara yang dapat digunakan untuk melihat perilaku pemilih dalam pemilu adalah dengan menggunakan pendekatan voting behavior (perilaku pemilih). Dieter Roth menyebutkan bahwa apabila kita membicarakan teori perilaku pemilih, maka tidak ada satu teori yang benar, karena juga tidak ada hanya satu teori mengenai perilaku manusia pada umumnya. Namun menurutnya, secara umum terdapat tiga macam pendekatan atau dasar pemikiran yang berusaha menerangkan perilaku pemilu, yaitu pendekatan sosiologis atau sosial struktural, model psikologi sosial, dan model pilihan rasional. (Fadjar. 2010). Menurut Dieter Roth, ketiga pendekatan ini tidak sepenuhnya berbeda, dan dalam beberapa hal ketiganya bahkan saling membangun dan mendasari serta memiliki urutan kronologis yang jelas. (Roth, 2009). Perbedaan antara ketiga pendekatan ini terletak pada titik beratnya satu sama lain.

Pertama, pendekatan sosiologis atau sosial struktural. Pendekatan ini menekankan pentingnya beberapa hal yang berkaitan dengan instrumen kemasyarakatan seseorang seperti, (a) status sosial ekonomi (seperti pendidikan, jenis pekerjaan, pendapatan, dan kelas), (b) agama, (c) etnik, dan (d) wilayah tempat tinggal (misalnya kota, desa, pesisir, ataupun pedalaman).

Kedua, pendekatan psikologis atau psikologi sosial. Model ini dikembangkan beberapa sarjana ilmu politik dari Michigan University di bawah The Michigan Survey Research Centre atau sering disebut sebagai Michigan's School. Dieter Roth menjelaskan bahwa para peneliti dari Michigan's School lebih melihat perilaku pemilu dengan mengkaji sang individu itu sendiri sebagai pusat perhatian mereka. Menurut mereka, persepsi dan penilaian pribadi terhadap sang kandidat atau tema-tema yang diangkat sangat berpengaruh terhadap pilihannya dalam pemilu. Selain itu, "keanggotaan psikologis" dalam sebuah partai dapat diukur juga dalam bentuk variabel identifikasi partai yang juga turut mempengaruhi keputusan atas pilihannya dalam pemilu. (Roth, 2009).

Ketiga, pendekatan pilihan rasional atau rational choice. Menurut Dieter Roth, pendekatan ini dipopulerkan oleh Downs yang mengasumsikan bahwa pemilih pada dasarnya bertindak secara rasional ketika membuat pilihan dalam tempat pemungutan suara (TPS), tanpa mengira agama, jenis kelamin, kelas, latar belakang orang tua, dan latar lainnya yang bersifat eksternal. Menurut Anthony Downs, dalam konteks pilihan rasional, ketika pemilih merasa tidak mendapatkan faedah dengan memilih partai atau calon presiden yang tengah berkompetisi, ia bahkan tidak akan 
melakukan pilihan pada pemilu. Mereka menggunakan pertimbangan-pertimbangan costs and benefits sebelum menentukan pilihan. Pertimbangan costs and benefits itu lebih didasarkan pada gagasan atau program-program yang bersentuhan dengan dirinya. Pendekatan ini kemudian dikembangkan oleh Morris P Fiorina dalam model keputusan pemilu restospektif.

Dalam model ini tampak bahwa teori perilaku pemilu yang rasional dan pendekatan sosial psikologis sejatinya dapat dikombinasikan dan dikomplementasikan satu sama lain. Perilaku pemilih dalam pemilu merupakan salah satu bagian dari kajian partisipasi politik. Menurut Sastroatmodjo, perilaku seseorang yang memilih partai tertentu dipengaruhi oleh beberapa sebab internal dan eksternal kehidupan seseorang seperti keadaan sistem politik, ekonomi, budaya, dan media masa. Selain itu dikatakan pengaruh keluarga, agama yang dianut pendidikan, dan hubungan personal di dalam masyarakat. (Sastroadmodjo, 1995).

Faktor lain juga membawa pengaruh seperti suasana iklim, keadaan internal keluarga dan lingkungan serta unsur pemaksaan dari pihak tertentu. Menurut Almond, perilaku memilih dalam pemilu terbentuk oleh pendidikan politik dalam keluarga, sekolah, teman sepergaulan, di tempat pekerjaan, pengaruh media masa dan hubungan pribadi dengan tokoh-tokoh politik. (Almond, Verba, 1965).

Menurut Sumarno (1989) menyatakan bahwa perilaku politik adalah tindakan atau emosi seseorang dalam suasana politik yang tertentu berasaskan kepada sikap atau persepsi, misalnya mendukung calon tertentu dalam sebuah pemilu, mendukung partai atau membangkang kepada pemerintahan. Persepsi dimaksudkan di sini adalah perilaku seseorang atau kumpulan masyarakat yang dirujukkan kepada keterkaitan faktor-faktor sosiologi dan psikologi serta keadaan ekonomi masyarakat maupun negara. Impak faktor tersebut menimbulkan minat seterusnya dilakukan dalam sikap perbuatan yang diinginkan seperti memilih partai atau memilih calon pemimpin tertentu.

Bagi seseorang yang telah mempunyai persepsi politik yang mendalam ia akan berpartisipasi politik dan memastikan pemilihan terhadap partai tertentu. Menurut Mar'at, bahwa persepsi politik adalah kesediaan seseorang untuk bertindak cerdas kepada objek politik sebagai tindak balas dari pemahaman mereka yang cukup mendalam mengenai politik dan apabila persepsi sudah ada di dalam pemahamannya, maka seseorang boleh memastikan sikap memilih partai yang disukainya. Oleh karena itu, persepsi politik adalah pemahaman seseorang terhadap sebuah konsep umum politik yang berpengaruh terhadap pola perilaku pemilihan saat pemilu dan perilaku seseorang untuk menyertai aktivitas politik semasa pemilu. (Mar'at, 1992).

Dengan demikian, perilaku pemilih adalah persepsi dan arah yang khas warganegara terhadap sistim politik yang memainkan peranan di dalam sistem pemerintahan tersebut. Tingkah laku seseorang akan terbentuk oleh adanya pengalaman, keterlibatan bersama-sama untuk menolak atau menerima setiap objek atau peristiwa politik. Di dalam proses demikian seseorang melakukan interaksi dengan pemerintah, masyarakat, kelompok maupun individu untuk membuat, melaksanakan dan menetapkan sebuah keputusan politik. 
Oleh karena itu, maka tingkah laku politik mempunyai makna yang berbedabeda bagi setiap orang dan tergantung kepada budaya politik di tempat mana ia berada dan perilaku politik mencakup aktivitas menetukan pilihan pemilu, menjadi anggota partai politik, mengadakan hubungan pribadi dengan orang-orang lain mengenai seluk beluk politik seperti dengan pihak elit pemerintah, elit politik dan sebagainya. Dalam konteks kajian pemilihan yang dapat mempengaruhi perilaku seseorang memilih antara lain ialah faktor-faktor sosiologi, psikologi dan ekonomi. Perilaku seseorang pemilih secara umum terpengaruh oleh faktor-faktor tersebut, ia menentukan sikap dan persepsi untuk ikut memilih. Misalnya seseorang memilih partai tertentu karena dorongan faktor psikologi dan sosiologi. Seseorang telah mengalami pengalaman hidup yang panjang di dalam pergaulan sosial, sikap politiknya dapat terbentuk karena pengaruh praktik politik keluarganya dan lingkungan tempat tinggal, termasuk juga pengaruh dari pergaulan dengan teman yang terlibat berpolitik. Seseorang juga terpengaruh memilih sebuah partai apabila mengharapkan keuntungan ekonomi dan ada pula karena pengaruh tokoh calon bertanding yang populer. Selain itu, pengaruh penyebaran informasi politik yang meluas melalui media masa terutama di kalangan masyarakat kota telah merubah persepsi dan pola berpikir masyarakat ke arah yang kritikal mengamalkan demokrasi yang sebenarnya sebagaimana yang berlaku di negara-negara maju. (Kristiadi, 1996).

\section{METODOLOGI}

Metode penelitian yang digunakan untuk mengetahui perilaku pemilih masyarakat di Kecamatan Jagakarsa, Jakarta Selatan pada Pemilihan Gubernur/Wakil Gubernur DKI Jakarta tahun 2017 yang lalu adalah metode campuran kualitatif dan kuantitatif. Metode penelitian campuran yang digunakan dalam penelitian ini tentu karena beberapa alasan. Pertama, adalah karena objek penelitian yang digunakan dalam kasus ini adalah sesuai dengan bentuk dinamika sosial yang cenderung berubah. Masyarakat pemilih dalam pilkada DKI Jakarta 2017 cenderung mempunyai pilihan yang berubah dibandingkan dengan pemilihanpemilihan sebelumnya. Kedua, penelitian ini berupaya untuk memberikan penjelasan mengenai perilaku masyarakat pemilih di wilayah penelitian. Penelitian ini mengambil 10 orang responden pada setiap Kelurahan. Terdapat 6 kelurahan di Kecamatan Jagakarsa. Responden adalah masyarakat yang sudah tergolong sebagai pemilih. Mereka tinggal di wilayah Kecamatan Jagakarsa. Dengan demikian jumlah responden adalah sebanyak 60 orang dan mereka ikut memilih dalam Pilkada Gubernur DKI Jakarta pada tahun 2017 yang lalu.

Selanjutnya, wilayah penelitian adalah Kecamatan Jagakarsa, Jakarta Selatan. Kecamatan Jagakarsa terdiri dari 6 kelurahan, yakni: Kelurahan Tanjung Barat, Kelurahan Lenteng Agung, Kelurahan Jagakarsa, Kelurahan Ciganjur, Kelurahan Srengseng Sawah, dan Kelurahan Cipedak. Kecamatan Jagakarsa memiliki keunikan persebaran pilihan. Cenderung tidak seragam antara satu kelurahan dengan kelurahan lain. Di Kelurahan Tanjung Barat misalnya, kemenangan pasangan Anies-Sandi tertinggi hingga mencapai 68,7 persen, sedangkan di Kelurahan Jagakarsa adalah terendah yaitu 62,4 persen. Selebihnya 
hampir tidak jauh berbeda perolehan suara Anis-Sandi di Kelurahan lain yang ada di Kecamatan Jagakarsa, yaitu antara 65-68 persen. Jadi meskipun secara keseluruhan pasangan Anies-Sandi memenangkan suara di Kecamatan Jagakarsa, namun terdapat keragaman perolehan suara di tigkat Kelurahan, meskipun tingkat keragamannya tidak terlalu signifikan perbedaannya.

\section{TEMUAN DAN ANALISA}

\section{Jumlah Pemilih Tetap di Kecamatan Jagakarsa, Jakarta Selatan}

Berdasarkan data yang diperoleh dari KPU, keseluruhan jumlah suara yang terdapat di Jakarta Selatan dalam Pilkada DKI Jakarta tahun 2017 adalah sebanyak 1.613.330 suara. Jumlah pemilih laki-laki adalah sebanyak 794.483 orang, sedangkan jumlah pemilih perempuan adalah sebanyak 800.739. Di dalam Pilkada DKI Jakarta tahun 2017 yang lalu itu, terdapat pengguna hak pilih sebesar 1.232.941 suara. Adapun tingkat partisipasi dalam Pilkada tersebut untuk wilayah Jakarta Selatan adalah sebesar 76,4 persen.

Masing-masing Kecamatan mempunyai jumlah suara yang berbeda-beda di wilayah Jakarta Selatan (Jumlah seluruh Kecamatan di wilayah Jakarta Selatan adalah 10 Kecamatan). Jumlah pemilih terbesar adalah Kecamatan Kebayoran Lama, yaitu 230.894 suara. Menyusul kemudian adalah Kecamatan Jagakarsa, yaitu sebanyak 227.731 suara. Sedangkan jumlah pemilih terkecil di wilayah Jakarta Selatan adalah di Kecamatan Setiabudi, yaitu 87.660 suara. Menyusul kemudian adalah di Kecamatan Mampang Prapatan, yaitu sebanyak 107.514 suara. Jumlah Pemilih di wilayah Jakarta Selatan dapat di lihat seperti tabel 1 di bawah ini.

Tabel 1. Jumlah Pemilih di Wilayah Jakarta Selatan dalam Pilkada DKI Jakarta Tahun 2017

\begin{tabular}{|c|l|l|l|l|l|l|}
\hline No & Kecamatan & $\begin{array}{l}\text { Jumlah } \\
\text { Pemilih }\end{array}$ & $\begin{array}{l}\text { Jumlah } \\
\text { Suara Sah }\end{array}$ & $\begin{array}{l}\text { Jumlah } \\
\text { Suara } \\
\text { Tidak } \\
\text { Sah }\end{array}$ & Total Suara & Partisipasi \\
\hline 1 & Cilandak & 158.108 & 115.650 & 1.861 & 117.503 & $74.6 \%$ \\
\hline 2 & Jagakarsa & 227.731 & 178.616 & 2.143 & 181.033 & $79.9 \%$ \\
\hline 3 & Kebayoran Baru & 114.691 & 83.151 & 1.120 & 84.295 & $74.1 \%$ \\
\hline 4 & $\begin{array}{l}\text { Kebayoran } \\
\text { Lama }\end{array}$ & 230.894 & 167.927 & 2.220 & 169.745 & $73.9 \%$ \\
\hline 5 & $\begin{array}{l}\text { Mampang } \\
\text { Prapatan }\end{array}$ & 107.514 & 83.592 & 836 & 84.431 & $79.4 \%$ \\
\hline 6 & Pancoran & 119.082 & 92.750 & 1.036 & 93.787 & $78.5 \%$ \\
\hline 7 & Pasar Minggu & 224.431 & 166.380 & 2.098 & 167.774 & $75.7 \%$ \\
\hline 8 & Pesanggarahan & 171.097 & 127.316 & 1.613 & 128.388 & $76.1 \%$ \\
\hline 9 & Setia Budi & 87.660 & 62.184 & 737 & 62.806 & $72.2 \%$ \\
\hline 10 & Tebet & 172.122 & 132.445 & 1.463 & 133.704 & $78.6 \%$ \\
\hline & Jumlah & 1.613 .330 & 1.210 .011 & 15.127 & 1.223 .466 & \\
\hline
\end{tabular}


Dalam Pilkada DKI Jakarta tahun 2017 yang lalu pemenangnya di wilayah Jakarta Selatan adalah pasangan calon gubernur Anies-Sandi. Secara keseluruhan, jumlah suara yang diperoleh pasangan Anies-Sandi adalah sebanyak 754.140 suara (62.13\%). Sedangkan pasangan Basuki-Djarot adalah 459.753 suara (37.87\%).

Kecamatan Jagakarsa adalah Kecamatan yang mempunyai jumlah pemilih terbesar kedua di wilayah Jakarta Selatan setelah Kecamatan Kebayoran Lama. Jumlah pemilih di Kecamatan Jagakarsa adalah sebanyak 227.731 suara. Dari jumlah ini, terdapat sebanyak 111.375 pemilih laki-laki dan 113.123 pemilih perempuan. Adapun jumlah pemilih terbesar di Kecamatan Jagakarsa dalam Pilkada Gubernur DKI Jakarta tahun 2017 yang lalu berada di Kelurahan Jagakarsa, yaitu sebanyak 48.931 suara. Jumlah pemilih terbesar kedua berada di Kelurahan Srengseng Sawah, yaitu sebesar 45.772 suara. Sedangkan jumlah pemilih terkecil di Kecamatan Jagakarsa berada di Kelurahan Cipedak, yaitu sebesar 28.034 suara. Jumlah pemilih di Kecamatan Jagakarsa dalam Pilkada DKI Jakarta tahun 2017 yang lalu adalah seperti pada tabel 2 di bawah ini.

Tabel 2. Jumlah Pemilih di Wilayah Kecamatan Jagakarsa dalam Pilkada DKI Jakarta Tahun 2017

\begin{tabular}{|c|l|l|l|l|l|l|}
\hline No & Kelurahan & $\begin{array}{l}\text { Jumlah } \\
\text { Pemilih }\end{array}$ & $\begin{array}{l}\text { Jumlah } \\
\text { Suara } \\
\text { Sah }\end{array}$ & $\begin{array}{l}\text { Jumlah } \\
\text { Suara } \\
\text { Tidak } \\
\text { Sah }\end{array}$ & $\begin{array}{l}\text { Total } \\
\text { Suara }\end{array}$ & Partisipasi \\
\hline 1 & Ciganjur & 30.832 & 23.750 & 283 & 24.033 & $79.1 \%$ \\
\hline 2 & Cipedak & 28.034 & 22.519 & 259 & 23.052 & $82.2 \%$ \\
\hline 3 & Jagakarsa & 48.931 & 37.979 & 400 & 38.379 & $78.4 \%$ \\
\hline 4 & $\begin{array}{l}\text { Lenteng } \\
\text { Agung }\end{array}$ & 42.661 & 33.834 & 514 & 34.348 & $81.1 \%$ \\
\hline 5 & $\begin{array}{l}\text { Srengseng } \\
\text { Sawah }\end{array}$ & 45.772 & 35.497 & 397 & 35.894 & $79.0 \%$ \\
\hline 6 & Tanjung Barat & 31.501 & 25.037 & 290 & 25.327 & $80.4 \%$ \\
\hline & JUMLAH & 227.731 & 178.616 & 2.143 & 181.033 & \\
\hline
\end{tabular}

Pemenang Pilkada DKI Jakarta tahun 2017 yang lalu di Kecamatan Jagakarsa adalah pasangan Anies-Sandi dengan perolehan suara sebesar 116.440 suara (64.94\%), sedangkan pasangan Basuki-Djarot adalah sebesar 62.867 suara (35.06\%). Kemenangan pasangan Anies-Sandi ini juga hampir merata di tingkat kelurahan di wilayah Kecamatan Jagakarsa dengan perolehan presentase di atas 60 persen setiap kelurahan. Sedangkan pasangan calon gubernur Basuki-Djarot hanya mendapatkan presentase perolehan suara sekitar 30 persen di tiap-tiap kelurahan yang berada di wilayah Kecamatan Jagakarsa. 


\section{Hasil Pilkada di Kecamatan Jagakarsa, Jakarta Selatan}

Pemungutan suara yang telah dilakukan pada putaran kedua yang diselenggarakan di kecamatan Jagakarsa Jakarta Selatan diputuskan. Pasangan calon nomor urut tiga adalah menjadi pemenangnya dan mengalahkan pasangan nomor urut dua. Pasangan Anies-Sandi memperoleh suara sebesar 116.440 suara (64.94\%), sedangkan pasangan Basuki-Djarot memperoleh suara sebesar 62.867 suara (35.06\%). Keseluruhan suara ini diperoleh dari 426 TPS yang berada di seluruh Kelurahan yang ada di wilayah Kecamatan Jagakarsa. Terdapat 111.375 orang pemilih laki-laki dan 113.123 orang pemilih perempuan. Pemilih disabilitas terdiri dari 135 orang, pengguna hak pilih disabilitas sebanyak 115 orang. Tingkat partisipasi pemilih disabilitas di Kecamatan Jagakarsa adalah 85,2\%.

Di Kelurahan Ciganjur jumlah pemilih adalah 30.832 orang. Suara sah adalah sebanyak 23.750 suara. Terdapat 283 suara yang tergolong tidak sah. Kemudian terdapat 62 TPS di Kelurahan Ciganjur. Tingkat partisipasi dalam pilkada DKI jakarta tahun 2017 yang lalu di Kelurahan Ciganjur adalah 79.1\%. Di Kelurahan Ciganjur, Kecamatan Jagakarsa ini pasangan Anies-Sandi memperoleh kemenangan dengan jumlah suara 15.056 suara (62.30\%). Sedangkan pasangan Basuki-Djarot adalah 9.111 suara $(37,70 \%)$.

Kemudian di Kelurahan Cipedak jumlah pemilih adalah 28.034 orang. Suara sah adalah sebanyak 22.519 suara. Selanjutnya terdapat juga suara yang tergolong tidak sah di kelurahan Cipedak ini, yaitu 259 suara. Di Kelurahan Cipedak terdapat sebanyak 57 TPS. Tingkat partisipasi dalam pilkada DKI jakarta tahun 2017 yang lalu di Kelurahan Cipedak adalah 82.2\%.

Selanjutnya di Kelurahan Jagakarsa jumlah pemilih adalah 48.931 orang. Suara sah adalah sebanyak 37.979 suara. Terdapat 400 suara yang tergolong tidak sah. Jumlah keseluruhan TPS di Kelurahan Jagakarsa ini adalah 89 TPS. Tingkat partisipasi dalam pilkada DKI jakarta tahun 2017 yang lalu di Kelurahan Jagakarsa ini adalah $78.4 \%$. Di Kelurahan ini pasangan Anies-Sandi memperoleh kemenangan dengan jumlah suara 23.703 suara $(62.38 \%)$, sedangkan pasangan Basuki-Djarot adalah 14.294 suara $(37,62 \%)$.

Berikutnya, hal yang tidak jauh berbeda dengan kelurahan-kelurahan sebelumnya, di Kelurahan Lenteng Agung jumlah pemilih adalah sebanyak 42.661 suara. Yang tergolong suara sah adalah sebanyak 33.834 suara dan suara tidak sah adalah sebanyak 514 suara. Jumlah TPS di kelurahan ini adalah 80 TPS. Tingkat partisipasi dalam pilkada DKI jakarta tahun 2017 yang lalu di Kelurahan Lenteng Agung ini adalah $81.1 \%$. sama dengan perolehan kemenangan pasangan AniesSandi sebelumnya, di Kelurahan Lenteng Agung ini pasangan Anies-Sandi juga berhasil unggul di atas $60 \%$, sedangkan pasangan Basuki-Djarot berada di bawahnya.

Kelurahan berikutnya di wilayah Kecamatan Jagakarsa ini adalah Kelurahan Srengseng Sawah. Di Kelurahan ini jumlah pemilih adalah sebanyak 45.772 orang. Suara sah adalah 35.497 suara dan suara tidak sah adalah sebanyak 397 suara. Jumlah TPS di Keluarahan Srengseng Sawah adalah sebanyak 79 TPS. Sedangkan tingkat partisipasi di keluarahan ini adalah 79,0\%. Di kelurahan ini perolehan suara 
untuk pasangan Anies-Sandi tidak jauh berbeda dengan di kelurahan-kelurahan sebelumnya, yakni sekitar 64\%.

Terakhir adalah di Kelurahan Tanjung Barat. Jumlah pemilih di kelurahan ini adalah sebanyak 31.501 orang. Terdapat 25.037 suara sah dan 290 suara tidak sah. Tingkat partisipasi 80,4\%. Jumlah TPS adalah 59 TPS. Pasangan Anies-Sandi berhasil menang di Kelurahan ini dengan jumlah presentase sebesar 64,5 persen.

Secara keseluruhan, pelaksanaan pilkada di Kecamatan Jagakarsa termasuk lancar dan aman. Terdapat sejumlah saksi dari masing-masing tim pendukung, baik yang berasal dari pasangan calon maupun yang independen. Sampai dengan pengumuman hasil perolehan suara disampaikan, tidak terapat hal-hal kejadian yang mengganggu proses pemilihan, baik di dalam bilik suara maupun di luar bilik suara.

\section{Analisa Perilaku Pemilih}

Jika dilihat secara seksama, maka terdapat tingkat partisipasi politik masyarakat yang cukup tinggi di wilayah penelitian penulis terkait kegiatan Pilkada DKI Jakarta 2017 yang lalu. Dalam penelitian ini, diperoleh hasil yang menunjukkan bahwa mayoritas responden, yaitu sebanyak 57 orang atau setara dengan $95 \%$, ternyata mengaku dan menyatakan bahwa mereka terlibat dalam pencoblosan pilkada DKI Jakarta 2017 yang lalu dengan memilih salah satu diantara calon kepala daerah yang tersedia di bilik-bilik suara.

\section{Aspek Sosiologis}

Aspek ini meliputi sejumlah karakteristik responden yang antara lain dari status sosial ekonomi pemilih, agama, etnisitas dan karakter wilayah tempat tinggal. Dari temuan data yang diperoleh sebagai hasil penelitian ini, terdapat 70 persen responden yang berjenis kelamin laki-laki yang memilih pasangan Anies-Sandi dalam Pilkada DKI Jakarta 2017 yang lalu. Besarnya jumlah pemilih yang berjenis kelamin laki-laki ini belum tentu menjadi cerminan realitas jumlah pemilih di seluruh wilayah DKI Jakarta, fakta ini hanya terdapat pada Kecamatan Jagakarsa, Jakarta Selatan saja.

Kemudian di lihat dari status sosial ekonomi pemilih, yang dikategorikan sebagai pemilih pasangan Anies-Sandi adalah para pemilih yang bekerja sebagai wiraswasta (45 persen) dan pedagang ( 33.3 persen). Para pemilih yang tergolong dengan status sosial semacam ini adalah pemilih yang dinilai sebagai orang yang mengetahui sisi negatif dan positif dari kandidat yang dipilihnya, sehingga sangat tertutup kemungkinan para pemilih dengan status sosial ekonomi semacam ini tidak paham akan arti dan program dari pilihannya. Di dalam penelitian ini memang tidak secara khusus peneliti mencari tahu pendapatan perbulan dari pemilih. Hal ini karena para pemilih enggan menyebutkan pendapatannya perbulan atau pertahun. Golongan pemilih seperti ini jelas merupakan sebagai pemilih yang mementingkan makna seorang kandidat.

Jika di lihat dari sisi pendidikan pemilih, ternyata terdapat temuan yang menunjukkan bahwa tamat SMA merupakan temuan paling dominan dari penelitian yang dilakukan peneliti, yaitu mencapai 48.3 persen. Temuan ini menunjukkan bahwa pemilih pasangan Anies-Sandi dalam Pilkada DKI Jakarta 2017 di wilayah 
penelitian Jagakarsa, ternyata bukanlah dari kalangan masyarakat yang berpendidikan tinggi. Terdapat persebaran yang cukup berarti dari pemilih yang berpendidikan menengah sebagai pemilih pasangan Anies-Sandi di wilayah penelitian ini. Dengan demikian dapat di simpulkan bahwa mayoritas pemilih pasangan Anies-Sandi adalah mereka yang memiliki tingkat pendidikan menengah.

Selanjutnya adalah indikator agama. Pemilih pasangan Anies-Sandi dalam Pilkada DKI Jakarta 2017 yang lalu di wilayah Jakakarsa Jakarta Selatan mayoritas beragama islam. Pemilih beragama islam adalah sebanyak 60 persen. Yang paling sedikit adalah mereka pemilih yang beragama hindu, yaitu hanya 3.3 persen saja. Pemilih yang menjatuhkan pilihannya kepada pasangan Anies-Sandi adalah mereka yang beragama islam, patut dipahami sebagai pemilih mayoritas adalah karena pasangan ini memang diusung oleh paling tidak partai politik berbasis islam, yaitu PKS, meskipun terdapat partai non-islam di dalamnya, yaitu partai Gerindra yang turut mendukung pasangat Anies-Sandi. Suara ummat islam ke pasangan AniesSandi dalam Pilkada DKI Jakarta 2017 yang lalu terlihat menguat justeru karena adanya penistaan kepada ajaran agama islam. Dapat dipastikan bahwa mengalirnya suara ummat islam ke pasangan Anies-Sandi dalam Pilkada di DKI Jakarta 2017 lalu, termasuk di wilayah penelitian penulis sangat terkait dengan adanya issu penistaan agama islam yang dilakukan oleh pasangan yang menjadi lawan tanding Anies-Sandi.

Indikator lain yang dapat dilihat dari aspek sosiologis ini adalah terkait dengan etnisitas pemilih. Jakarta sebagai kota metropolis menjadi titik temu berbagai golongan dan etnis di Indonesia, karena itu kalau dilihat secara etnis komposisi penduduk Jakarta sangat beragam. Hasil Sensus Penduduk yang dilakukan BPS tahun 2010 menunjukkan komposisi penduduk Jakarta berdasarkan etnis adalah etnis Jawa $36.64 \%$, disusul oleh etnis Betawi $28.65 \%$, Sunda $14.8 \%$, Tionghoa $6,71 \%$, dan sisanya etnis-etnis lainnya.

Hal ini menarik kalau kita kaitkan dengan konteks pertarungan di Pilkada Jakarta, bagaimana para kandidat memperebutkan suara pemilih yang multi etnis tadi. Pemetaan pemilih biasa dilakukan dalam kontestasi pemilu, pemetaan itu bisa berbasis nilai-nilai (values), ideology, perilaku pemilih, atau yang lebih mendasar berdasarkan geografi atau demografi seperti umur, jenis kelamin, agama, atau etnis. Di Amerika yang memiliki sejarah tradisi demokrasi yang sangat panjang, analisis pengaruh etnis dan agama terhadap preferensi pemilih dalam memilih partai atau kandidat presiden banyak dilakukan. Pew Research Center, misalnya, dalam banyak kajiannya kita bisa menemukan pemilih kulit putih protestan di Amerika Serikat menjadi pendukung utama Partai Republik, sementara Partai Demokrat pemilihnya lebih beragam dari sisi etnis dan agama, termasuk didalamnya etnis hispanik dan pemilih kulit hitam.

Kembali soal Pilkada Jakarta, kita bisa melihat bukan hanya soal pemilih yang beragam, tapi kandidatnya pun latar belakang etnisnya juga beragam, Petahana Pak Basuki Tjahaja Purnama yang Tionghoa, Pak Anis Baswedan yang Arab, Mas Agus Yudhonyono yang Jawa, dan ada juga Ibu Sylvia yang Betawi. Tentu saja merupakan fenomena yang bagus terhadap demokrasi di Indonesia. Apakah beragamnya kandidat etnis berpengaruh terhadap faktor pertimbangan pemilih 
dalam menentukan kandidat gubernur yang mereka pilih?. Temuan survei yang dilakukan Alvara Research Center biasanya memang menyebutkan bahwa persoalan etnis dan agama selalu menjadi pilihan buncit pemilih dalam menentukan siapa kandidat yang akan mereka pilih disetiap pemilu. Pemilih lebih mempertimbangkan soal kapabilitas dan kapasitas kandidat yang mereka pilih. Pertanyaan berikutnya apakah boleh berkampanye menggunakan etnis dan agama sebagai dasarnya?

Kita tidak bisa menghindari kenyataan bahwa memang ada pemilih yang memilih karena ada kesamaan etnis dan agama. Sebagian teman-teman Tionghoa tentu saja lebih nyaman memilih Pak Basuki, sebaliknya mungkin sebagian temanteman Islam mungkin lebih nyaman memilih Pak Anis, atau sebagian orang Jawa mungkin lebih nyaman memilih Mas Agus, dan seterusnya. Tapi perlu diingat preferensi memilih karena faktor etnis dan agama adalah preferensi paling "primitif" dalam pemilu.

Para pemilih yang memilih pasangan Anies-Sandi dalam Pilkada DKI Jakarta 2017 lalu di lokasi penelitian penulis adalah mereka yang mayoritas beretnik Sunda, yakni mencapai 30 persen. Jadi tidak terdapat hubungan kemenangan pasangan Anies-Sandi dengan asal etnik pemilih. Dalam konteks ini, asal etnik pemilih tidak terlalu berpengaruh bagi munculnya perilaku pemilih yang menjatuhkan pilihannya kepada pasangan Anies-Sandi dalam Pilkada DKI Jakarta di lokasi penelitian penulis.

Indikator terakhir dari aspek sosiologis ini adalah menyangkut pada karakter wilayah tempat tinggal. Karakter wilayah tempat tinggal para pemilih di Jagakarsa jelas adalah wilayah perkotaan. Wilayah perkotaan ini menyangkut pada mudahnya masyarakat pemilih mengakses setiap ciri perkotaan, baik media, transportasi, dan fasilitas sosial ekonomi menjadi salah satu ciri khas masyarakat perkotaan. Oleh karena itu karakter wilayah tempat tinggal ini menjadi penentu bagi lancarnya koneksifitas pemilih antara satu tempat tinggal dengan tempat tinggal lain. Di wilayah semacam ini tidak terdapat tempat tinggal pemilih yang masuk dalam kategori tempat kumuh. Dengan demikian para pemilih pasangan Anies-Sandi dalam Pilkada DKI Jakarta 2017 yang lalu, khususnya di lokasi penelitian Jagakarsa Jakarta Selatan termasuk wilayah perkotaan.

\section{Aspek Psikologis}

Aspek psikologis dalam penelitian ini adalah segala hal yang terkait dengan persepsi dan penilaian pribadi pemilih terhadap pasangan Anies-Sandi dalam Pilkada DKI Jakarta 2017 yang lalu. Indikator yang dianggap melekat dalam dimensi persepsi ini adalah pandangan responden terhadap keberanian calon pasangan serta bukti bersihnya pasangan calon dari sejumlah kasus yang ada. Selain indikator ini, terdapat juga tema-tema kampanye yang diangkat oleh pasangan Anies-Sandi. Hal yang ingin di lihat terutama adalah pandangan responden terhadap kemampuan memimpin Jakarta dan memecahkan segala masalah yang dihadapi Jakarta. Selanjutnya adalah keberpihakan pada kepentingan masyarakat Jakarta dan kedekatan pasangan Anies-Sandi dengan warga Jakarta, pandangan terhadap partai pengusung serta performa pasangat Anies-Sandi. 
Ada sejumlah faktor psikologis yang bisa pengaruhi pilihan pemilih calon pemimpin. Pertama, cara para calon pemimpin mengeksprean diri mereka bisa pengaruhi keputusan seseorang untuk memilihnya. Jadi jika dilihat dari sudut pandang psikologi, seseorang cenderung akan lebih memilih calon pemimpin yang karakter serta gaya mengekspresikan aspirasinya mirip dengan dirinya. Memilih orang yang memiliki sifat tidak jauh berbeda darinya akan membuatnya merasa lebih nyaman dan terjamin kesejahteraannya.

Kedua, pemilih bisa terpengaruh apabila dihantui rasa takut dimusuhi, dijauhi dan diisolasi oleh orang-orang terdekat atau orang lain yang jumlahnya termasuk dalam kategori mayoritas. Ia akan rela menyembunyikan pilihan aslinya di depan orang lain dan berlagak seolah satu suara dengan yang lainnya agar lebih mudah diterima. "Tekanan sosial yang berasal dari berbagai sumber seperti keluarga, teman, pasangan, pengusaha, pemimpin agama dan lainnya pasalnya memicu respon psikologis pada si pemilih,"

Ketiga, tingkat kecerdasan pemilih mengendalikan psikologisnya dengan membuatnya lebih mungkin memilih calon pemimpin yang tidak hanya mencerminkan perilaku positif namun juga memiliki wawasan luas.

Keempat, tindakan berperikemanusiaan calon pemimpin. Pemilih cenderung akan lebih bulat tekadnya untuk memilih calon pemimpin yang bisa menjanjikan bantuan pada orang yang kesusahan, serta keamanan terhadap kesejahteraan masingmasing individu.

Kelima, seorang pemilih akan lebih mungkin memilih seorang calon pemimpin yang secara fisik dipandang menarik. Fisik yang menarik kerap diasosiasikan dengan karakteristik yang juga menarik seperti otak yang cerdas dan jiwa yang ramah.

Sebelum jauh membahas aspek psikologis pemilih, ada baiknya diuraikan terlebih dahulu tingkat pengenalan calo pasangan bagi pemilih. Secara umum, mayoritas responden mengatakan bahwa pasangan Anies-Sandi sudah cukup dikenal oleh para pemilihnya. Terdapat 70 persen responden menyatakan mengenal pasangan Anies-Sandi sebagai calon Gubernur DKI Jakarta saat 2017 yang lalu. 21.6 persen menyatakan dengan sangat mengenal dan hanya 8.3 persen saja yang menyatakan tidak mengenal pasangan Anies-Sandi. Tingkat pengenalan ini memang tidak secara penuh mengenal luar dalam sosok pasangan Anies-Sandi, melainkan mengenal sosok tersebut lewat program-program yang diusungnya atau lewat imaji sosok yang diperkenalkan oleh tim pemenangan Anies-Sandi. Terbukti, para responden mayoritas mengakui bahwa mengetahui banyak tentang sosok pasangan Anies-Sandi adalah lewat tim sukses dan media informasi. Terdapat sebesar 53.3 persen mengakui mengetahui sosok pasangan dari tim sukses dan 25 persen mengetahuinya dari media informasi. Artinya peran tim sukses pasangan AniesSandi sangat besar dalam rangka mengenalkan pasangannya sehingga dapat dijadikan sebagai pilihan dalam Pilkada DKI Jakarta 2017 yang lalu.

Kemudian beralih ke program pasangan Anies-Sandi, mayoritas responden mengemukakan bahwa 40 persen mengetahui program-program kampanye yang ditawarkan pasangan tersebut, kemudian terdapat 33.3 persen yang mengatakan tidak tahu dan hanya 26.6 persen saja yang tidak menjawab. Ini artinya bahwa 
sebagian besar respoden mengetahui program-program kerja yang ditawarkan pasangan Anes-Sandi dalam Pilkada DKI Jakarta 2017 yang lalu di lokasi penelitian penulis. Dari sisi ini sebenarnya sudah terlihat dengan jelas bahwa, pengenalan terhadap program paralel dengan kedekatan sang calon dengan masyarakat yang memilihnya. Dengan demikian secara tidak langsung faktor psikologis pemilih lebih dekat dengan pasangan Anies-Sandi karena program-programnya dinilai lebih menyentuh kepentingan dan keinginan masyarakat pemilih. Sisi lain dari makna ini dapat juga dikemukakan bahwa pasangan Anies-Sandi dinilai dekat dengan massyarakat pemilihnya. Inilah juga salah satu aspek yang membuat atau menyebabkan pasangan Anies-Sandi memperoleh suara terbanyak pada Pilkada DKI Jakarta di Kelurahan Jagakarsa pada Pilkada 2017 yang lalu.

Persepsi masyarakat atau aspek psikologis masyarakat pemilih di lokasi penelitian penulis juga menunjukkan adanya kecenderungan yang mengarah pada kepercayaan pemilih bahwa program dan kepribadian pasangan Anies-Sandi dinilai sangat bertanggungjawab terhadap masyarakat pemilih di Jakarta secara umum dan khususnya di Kelurahan Jagakarsa Jakarta Selatan. Apalagi sang calon dinilai juga bersih dari terpaan kasus-kasus hukum dan kriminal yang menyertainya. Terbukti bahwa pandangan pemilih terhadap perilaku pasangan Anies-Sandi, mayoritas mengemukakan bahwa pasangan ini berkelakuan baik, yaitu mencapai 61.6 persen. Dan hanya 16.6 persen saja yang mengaku bahwa pasangan ini berkelakuan buruk. Kemungkinan terbesar dari munculnya pandangan buruk para pemilih terhadap pasangan Anies-Sandi ini adalah pihak-pihak yang memang tidak memilih pasangan ini pada Pilkada DKI Jakarta 2017 yang lalu.

\section{Aspek Rasional}

Pandangan umum tentang penggunaan aspek rasional terkait pemilihan kepala daerah menyangkut pada kinerja yang ditunjukkan oleh para calon pemimpin. Sampai dengan putaran pertama berlangsung dalam pilkada DKI Jakarta 2017 lalu, terlihat bahwa aspek rasionalitas masih menonjol, ditandai dengan berhasilnya pasangan Ahok-Djarot meraih suara terbanyak, yakni hingga 43 persen. Putaran pertama ini menampilkan kuatnya rasionalitas pemilih, dengan penilaian keberhasilan sejumlah program yang dijalankan petahana, seperti menata kota, memperbaiki kemacetan Jakarta, dan menata pemerintahan daerah. Ketika itu pasangan Anies-Sandi hanya memperoleh kemenangan 40 persen sampai dengan putara pertama. Saat itu, banyak analis yang mengklaim bahwa warga Jakarta sangat rasional. Meski Ahok dihantam isu-isu primordial dan SARA warga Jakarta tetap memilihnya karena menilai kinerja calon petahana ini di atas rata-rata.

Kemenangan Ahok-Djarot dalam putaran pertama ini bisa dibaca dalam dua perspektif yang berbeda. Di tengah tekanan kuat pasca kontroversi Al Maidah dan status Ahok sebagai terdakwa dalam kasus dugaan penodaan agama, perolehan suara pada kisaran 43 persen dan tampil sebagai pemenang di putaran pertama tentu tidak buruk. Artinya, klaim bahwa warga Jakarta rasional menemukan justifikasi empirisnya. Namun, kemenangan tipis tersebut bisa juga dibaca sebaliknya. Menurut data longitudinal Indikator Politik Indonesia, rata-rata kepuasan publik terhadap Ahok mencapai 73,4 persen. Masih banyak proporsi pemilih yang puas atas kinerja 
Ahok, tetapi tidak sudi memilihnya. Jika benar warga Jakarta rasional, seharusnya Ahok minimal mengantongi suara 70 persen sesuai dengan proporsi warga yang puas terhadap kinerjanya. Dengan kata lain, perolehan suara ketiga pasangan calon di Jakarta tidak bisa dijelaskan semata-mata oleh faktor rasionalitas. (Muhtadi, https://nasional.kompas.com/read)

Inilah anomali politik electoral (Firmansyah, 2012). Pada umumnya terdapat korelasi yang sangat konsisten dan kuat antara kinerja petahana dengan tingkat kedipilih-an. Secara rasional, warga mengakui kinerja Ahok dalam mengatasi banjir dan masalah sampah, meningkatkan pelayanan di kantor-kantor pemerintahan, dan lain-lain. Meski masih belum puas dalam mengatasi kemacetan, warga juga melihat usaha konkret pemerintah provinsi dalam membangun sarana transportasi massal.

Namun, tingginya approval rating Ahok tidak otomatis mengangkat elektabilitasnya. Hal ini menjadi bukti bahwa "kepala" dan "hati" sebagian warga Jakarta terbelah. Mereka mengakui kinerja petahana baik, tetapi hati mereka sulit menerima Ahok. Inilah yang disebut George Orwell sebagai gejala doublethink yang dalam konteks ini dipahami sebagai "kemampuan seseorang untuk memercayai dua hal yang bertolak belakang secara bersamaan tanpa merasa bersalah atau tidak nyaman (disonansi kognitif). Basis dukungan Ahok sangat kuat pada aspek rasional, tetapi lemah pada dimensi emosional. Oleh sebab itu aspek rasionalitas sangat tidak konsisten terlihat dalam kemenangan Anies-Sandi pada Pilkada DKI Jakarta 2017 yang lalu. Yang muncul justeru adalah kuatnya dimensi emosional dalam melihat kemenangan pasangan Anies-Sandi.

Faktor rasional (evaluasi atas kinerja petahana) dan faktor emosional ( $\mathrm{Al}$ Maidah) secara bersama-sama kuat dan signifikan pengaruhnya terhadap pilihan, terlepas dari bagaimanapun kondisi faktor-faktor lainnya (evaluasi atas kondisi ekonomi, kedekatan dengan partai, dan faktor-faktor sosiologis: jender, umur, pendidikan, suku bangsa, dan agama). Hasil putaran pertama ini, sekali lagi, menunjukkan bahwa aspek rasionalitas tak seluruhnya bisa menjelaskan perilaku pemilih.

Temuan data yang diperoleh penulis menunjukkan bahwa pasangan AhokDjarot dinilai berkelakuan buruk, yakni sebanyak 70 persen adalah bukti betapa sisi rasionalitas ternyata tidak sepenuhnya bekerja dengan baik. Dengan demikian aspek rasionalitas pemilih tidak dapat digunakan dalam melihat kemenangan Anies-Sandi. Justeru faktor emosional pemilih lebih kuat mempengaruhi kemenangan pasangan Anies-Sandi dalam Pilkada DKI Jakarta 2017 yang lalu di wilayah penelitian penulis. Sentimen agama telah berhasil dimanfaatkan dengan cerdas oleh pasangan Anies-Sandi dalam pilkada tersebut. Rasional karena mengikuti arah pilihan kelompok (group-oriented voting). Individu mengikuti orientasi pilihan kelompok karena logika menjaga harmoni komunitas dan manfaat materi yang diterima oleh kelompok (patronage).

Logika mengikuti arah pilihan kelompok ini sebenarnya adalah kategori pilihan rasional yang penuh dengan perdebatan. Penanda hadirnya pemilih rasional sepertinya cukup sederhana melalui tiga indikator, yaitu kalkulasi, kesesuaian dan pertimbangan strategis. Dapat disimpulkan bahwa pemilih rasional yang menjatuhkan pilihannya ke pasangan Anies-Sandi ini termasuk dalam pertimbangan 
strategis. Jadi masih tetap dalam kategori pemilih rasional. Terdapat beberapa indikasi yang menunjukkan hal itu antara lain adalah karena logika pemilih yang tergolong arah pilihan kelompok (group-oriented voting) untuk tujuan menjaga harmoni dan keberlangsungan kelompok. Hal ini sebenarnya sama saja dengan gejala yang menunjukkan penguatan kelompok tertentu atau hadirnya sebuah polarisasi. Inilah ciri utama pilihan rasional dari kemenangan pasangan Anies-Sandi dalam pilkada DKI Jakarta 2017 yang lalu.

\section{SIMPULAN}

Berdasarkan temuan data yang diperoleh penulis dari lapangan, dapat dijelaskan bahwa ketiga faktor di atas (sosiologis, psikologis dan rasional) sesungguhnya berperan secara bersama bagi pemilih di Kecamatan Jagakarsa untuk menentukan pilihannya kepada pasangan Anies-Sandi. Namun demikian, bahwa faktor rasional dan emosional yang paling berperan bagi pemilih untuk menjatuhkan pilihannya kepada pasangan Anies-Sandi di Kecamatan Jagakarsa, Jakarta Selatan dalam Pilkada DKI Jakarta 2017 yang lalu.

Faktor rasional karena para pemilih adalah mereka yang berasal dari kalangan masyarakat menengah ke atas, para pemilih juga memiliki status sosial yang tergolong menengah ke atas, dan oleh karenanya para pemilih masuk dalam kategori rasional. Selain dari pada itu program-program kerja yang disampaikan pasangan Anies-Sandi adalah anti tesa dari program-program kerja yang disampaikan oleh pasangan Ahok-Djarot. Sedangkan faktor emosional lebih pada kasus penodaan agama islam yang sebelumnya pernah dilontarkan Ahok (Al Maidah ayat 51). Bersamaan dengan itu harus dipahami bahwa masyarakat Jakarta adalah mayoritas islam, sehingga banyak yang tidak bersimpati dengan Ahok-Djarot, sehingga pilihannya lebih banyak kepada pasangan Anies-Sandi. Dimensi rasional, terutama yang menyangkut prtimbangan kalkulasi, kinerja memang lebih lekat pada pasangan Ahok-Djarot, tetapi pertimbangan strategis menjadi milik pasangan AniesSandi. Masyarakat pemilih di wilayah Jakagarsa, Jakarta Selatan yang menjadi lokasi penelitian penulis ternyata tidak cukup puas dengan capaian-capaian keberhasilan petahana (Ahok-Djarot) atau keberhasilan kinerjanya. Masyarakat pemilih di lokasi penelitian penulis ini tampak memberi syarat kepada capaiancapaian tersebut, syarat utama yang ditempelkan pada capaian keberhasilankeberhasilan tersebut adalah perlunya untuk tidak mengganggu nilai dan kepercayaan masyarakat pemilihnya. Hal inilah sesungguhnya yang membuat para pemilih tidak menjatuhkan pilihannya kepada pasangan Ahok-Djarot.

Kemenangan Anies-Sandi dalam Pilkada DKI Jakarta 2017 yang lalu menampilkan perbedaan yang mencolok atas pasangan Ahok-Djarot. Perolehan suara antara keduanya memiliki jarak yang sangat jauh yaitu kurang lebih $15 \%$, hal ini berbanding terbalik dengan elektabilitas Ahok-Djarot sebelum pesta demokrasi berlangsung. Berbedanya elektabilitas dan perolehan suara pasangan Ahok-Djarot menjadi pelajaran penting untuk diketahui. Perbedaan ini terjadi karena berbagai faktor. Pertama, masyarakat tidak simpati dengan bahasa dan komunikasi yang digunakan Ahok sebagai seorang pemimpin, sehingga sekalipun masyarakat merasa puas atas kinerja Ahok, masyarakat pemilih justeru memiliki keputusan untuk tidak 
memilih Ahok di Pilkada tersebut. Kedua, kekhawatiran masyarakat pemilih Jakarta munculnya persoalan baru, dimana masyarakat Jakarta dinilai akan terpecah belah. Ketiga, karena efek gelombang kasus 'penista agama' yang menjadi perhatian masyarakat. Pada taraf ini, elektabilitas yang tinggi ternyata tidak mendorong naiknya perolehan suara.

Efek penista agama yang melekat pada diri Ahok telah menjadi isu yang paling kuat melekat di dalam pandangan masyarakat pemilih, mungkin tidak hanya di lokasi penelitian penulis, melainkan di seluruh wilayah Jakarta. Mayoritas responden mengaku bahwa karena Ahok terlibat sebagai penista agama maka keterpilihannya menjadi menurun. Pada titik inilah sesungguhnya yang membuat dimensi kinerja positif bagi pasangan Ahok-Djarot tidak lagi paralel dengan keterpilihannya. Artinya dimensi pilihan rasional tidak seiring dengan capaiancapaian positif atau kinerja yang baik dari pasangan Ahok-Djarot.

\section{DAFTAR PUSTAKA}

Fadjar, AM Muktie. (2010). Konstitusionalisme Demokrasi. Malang: In-TRANS Publishing.

Kristiadi, J. (2008). Darurat Partai Politik. Jakarta: Ghalia Indonesia.

Mar'at. (1992). Sikap Manusia, Perubahan Serta Pengukuran. Jakarta: Ghalia Indonesia.

Muhtadi, Burhanuddin, https://nasional.kompas.com, 30/04/2017.

Putra, Fadillah. (2003). Paradigma Kritis Dalam Studi Kebijakan Publik. Yogyakarta: Pustaka Pelajar.

Roth, Dieter. (2009). Studi Pemilu Empiris, dalam Dodi Ambardi. ed, Teori-teori Instrumen dan Metode. Jakarta: Frederick Neumenn Stiftung dan LSI,.

Sastroadmodjo, Sudianto. (1995). Perilaku Politik. Semarang: IKIP Semarang Press.

Sumarno. (1989). Dimensi-Dimensi Komunikasi Politik. Bandung: Citra Aditya Bakti.

Surbakti, Ramlan. (1997). Partai, Pemilih dan Demokrasi. Yogyakarta: Pustaka Pelajar.

Surbakti, Ramlan. (1992). Memahami Ilmu Politik. Jakarta: Gramedia Widiasarana Indonesia. 